\title{
APLIKASI RESPONSE SURFACE METHODOLOGY PADA OPTIMALISASI KONDISI PROSES PENGOLAHAN ALKALI TREATED COTTONII (ATC)
}

\section{Application of Response Surface Methodology in The Optimization of Process Conditions of Alkali Treated Cottonii (ATC) Processing}

\author{
Sitti Nurmiah ${ }^{1 *}$, Rizal Syarief ${ }^{2}$, Sukarno ${ }^{2}$, Rosmawaty Peranginangin ${ }^{3}$, dan Budi Nurtama ${ }^{2}$ \\ ${ }^{1}$ Jurusan IImu Pangan Fakultas Teknologi Pertanian Institut Pertanian Bogor. Jl. Raya Dramaga, \\ Gedung Andi Hakim Nasoetion, Kampus IPB Darmaga Bogor, Jawa Barat \\ ${ }^{2}$ Program Studi IImu Pangan, Institut Pertanian Bogor. JI. Raya Dramaga, \\ Gedung Andi Hakim Nasoetion, Kampus IPB Darmaga Bogor, Jawa Barat \\ ${ }^{3}$ Balai Besar Penelitian dan Pengembangan Pengolahan Produk dan Bioteknologi Kelautan dan Perikanan, KKP. \\ JI. K.S. Tubun Petamburan VI, Jakarta Pusat 10260 \\ * Korespondensi Penulis: miah_patur@yahoo.com
}

Diterima: 15 Juni 2012, Disetujui: 9 Januari 2013

\begin{abstract}
ABSTRAK
Alkali Treated Cottonii (ATC) merupakan hasil olahan rumput laut merah (Eucheuma cottonii) dengan perlakuan alkali. Kondisi proses seperti konsentrasi $\mathrm{KOH}$, suhu dan waktu proses akan berpengaruh pada kuantitas dan kualitas ATC yang dihasilkan. Tujuan dari penelitian ini adalah untuk mengidentifikasi hubungan antara variabel input dan mengembangkan model prediksi yang digunakan dalam mengoptimalisasi kondisi proses pengolahan ATC. Program Design Expert $7.0^{\circledR}$ dengan Response Surface Methodology (RSM) Box-Behnken Design digunakan untuk meneliti dan memilih kondisi proses dari kombinasi tingkat faktor yang menghasilkan respon yang optimal. Berdasarkan RSM Box-Behnken Design diketahui bahwa efek utama dari konsentrasi $\mathrm{KOH}$, suhu dan waktu pengolahan merupakan faktor yang sangat berpengaruh terhadap nilai respon ATC. Hubungan antara variabel terhadap respon rendemen ATC dimodelkan $Y=-0,97 A+6,59 B-1,79 C-0,045 B^{2}$, sedangkan nilai kekuatan gel dimodelkan $Y=29030,24 A+$ $1488,61 B-521,90 C-406,91 A B-64,50 A C-1984,79 A^{2}+344,21 C^{2}+28,02 A^{2} B$. Nilai respon optimal ATC adalah 92,8\%, dengan kondisi proses pengolahan konsentrasi $\mathrm{KOH} 6 \%$, suhu $78.67^{\circ} \mathrm{C}$ dengan waktu 1 jam.
\end{abstract}

KATA KUNCI: alkali treated cottonii, optimalisasi, response surface methodology, karaginan

\begin{abstract}
Alkali Treated Cottonii (ATC) is processed from red algae (Eucheuma cottonii) with alkali treatment. Process condition e.q. $\mathrm{KOH}$ concentration, temperature and process time will effect the yield and quality of the resulted ATC. The purpose of this study was to identify the relationship between input variables and process response and to develop predictive models that can be used in optimizing the processing conditions of the ATC. Program Design Expert (DX) $7.0^{\circledR}$ with Response Surface Methodology (RSM) Box-Behnken Design was used to investigate and select the combination of factor levels that produced the optimal response. Based on the RSM-BoxBehnken Design approach, it was known that the main effects of $\mathrm{KOH}$ concentration, temperature and process time were the most significant factors to the value of ATC response. The relationship between the response variable was modeled of ATC yield as $\mathrm{Y}=-0.97 \mathrm{~A}+6.59 \mathrm{~B}-1.79 \mathrm{C}-0.045 \mathrm{~B}^{2}$ while the gel strength values was modeled as $\mathrm{Y}=29030.24 \mathrm{~A}+1488.61 \mathrm{~B}-521.90 \mathrm{C}-406.91 \mathrm{AB}-$ $64.50 \mathrm{AC}-1984.79 \mathrm{~A}^{2}+344.21 \mathrm{C}^{2}+28.02 \mathrm{~A}^{2} \mathrm{~B}$. ATC optimal response value was $92,8 \%$, and the optimum processing conditions was: $6 \%$ of $\mathrm{KOH}$ concentration, $78,67^{\circ} \mathrm{C}$ of temperature and $1 \mathrm{~h}$ of time.
\end{abstract}

KEYWORDS: alkali treated cottonii, optimization, response surface methodology, carrageenan 


\section{PENDAHULUAN}

Produksi rumput laut Indonesia dari tahun ke tahun mengalami peningkatan. Berdasarkan data Kementerian Kelautan dan Perikanan (2012), volume produksi rumput laut nasional tahun 2011 mencapai 416.272 ton berat kering, dan sekitar 349.792 ton dari jenis Eucheuma cottonii. Hal tersebut menjadikan Indonesia sebagai produsen utama rumput laut di dunia.

Di Indonesia, sejak dicanangkan rumput laut sebagai salah satu komoditas yang direvitalisasi, orientasi pemanfaatannya sebagai komoditas ekspor dalam bentuk raw material sudah mulai bergeser menjadi produk yang bernilai tambah, terutama dalam bentuk alkali treated cottonii (ATC).

ATC merupakan hasil olahan rumput laut merah (Eucheuma cottonii) dengan perlakuan alkali (alkalinisasi). Di samping dapat digunakan sebagai bahan baku pembuatan karaginan murni (refined carrageenan), produk ATC diminati industri-industri pengolah di Eropa, Amerika dan Asia Pasifik, karena dapat diproses lebih lanjut sebagai pembentuk gel, penstabil dan pengatur keseimbangan dalam industri non pangan terutama makanan ternak (Mc Hugh, 2003).

Proses alkalinisasi pada pengolahan ATC, merupakan proses perlakuan basa yang bertujuan mengubah residu prekursor dengan menghilangkan beberapa kelompok sulfat dari molekul dan meningkatkan kekuatan gel (Mc Hugh, 2003). Proses alkalinisasi yang efektif akan menghasilkan ATC dengan rendemen dan kekuatan gel yang maksimal. Variabel yang mempengaruhi proses alkalinisasi, di antaranya konsentrasi alkali, suhu dan waktu proses.

Penelitian yang terkait dengan proses pengolahan ATC, telah dilakukan oleh Basmal et al. (2005) dengan berbagai konsentrasi $\mathrm{KOH}$ dengan waktu pemasakan 2 jam pada suhu $70-80^{\circ} \mathrm{C}$, dan rendemen yang dihasilkan 29,3\% dengan kekuatan gel sebesar 578,5 $\mathrm{g} / \mathrm{cm}^{2}$; Tuvikene et al. (2006) melakukan pengolahan dengan berbagai jenis pelarut (air, $\mathrm{KOH}$ dan $\mathrm{NaOH}$ ); Mehta et al. (2008) preparasi SRC dengan pelarut $\mathrm{KOH} 8 \%$, dengan kondisi optimum proses pengolahan suhu $78-82^{\circ} \mathrm{C}$, waktu 2-3 jam; Mustapha et al. (2011), pengolahan SRC dengan variasi suhu, jenis dan konsentrasi pelarut yang berbeda, dan menghasilkan kondisi optimum dengan pelarut $\mathrm{KOH}$ pada konsentrasi $1,0 \mathrm{M}$ pada suhu $80^{\circ} \mathrm{C}$ dengan waktu 1 jam.

Kondisi proses pengolahan yang bervariasi dalam menghasilkan ATC, menjadi pertimbangan dalam penentuan kuantitas dan kualitasnya. Oleh karena itu, pada penelitian ini digunakan Program Design
Expert (DX) 7.0 ${ }^{\circledR}$ RSM Box-Behnken Design untuk menyelidiki dan memilih kondisi proses dari kombinasi konsentrasi $\mathrm{KOH}$, suhu, dan waktu pengolahan terhadap rendemen dan kekuatan gel. Kelebihan dari program ini dapat digunakan untuk analisis dan pemodelan dari suatu permasalahan dengan satu atau lebih perlakuan dalam penelitian (Montgomery, 2001; Bas \& Boyaci, 2007; Raissi \& Farsani, 2009). Menurut Radojkovic et al. (2012), RSM adalah kumpulan statistik dan matematika teknik yang berguna untuk mengembangkan, meningkatkan, dan mengoptimalkan proses, di mana respon dipengaruhi oleh beberapa faktor (variabel independen). Response Surface Methodology (RSM) tidak hanya mendefinisikan pengaruh variabel independen, tetapi juga menghasilkan model matematis, yang menjelaskan proses kimia atau biokimia. Gagasan utama dari metode ini adalah mengetahui pengaruh variabel bebas terhadap respon, mendapatkan model hubungan antara variabel bebas dan respon serta mendapatkan kondisi proses yang menghasilkan respon terbaik. Di samping itu, keunggulan metode RSM ini di antaranya tidak memerlukan data-data percobaan dalam jumlah yang besar dan tidak membutuhkan waktu lama (Iriawan \& Astuti, 2006).

Tujuan dari penelitian ini adalah untuk mengoptimalkan kondisi proses pengolahan (konsentrasi $\mathrm{KOH}$, suhu dan waktu) pada pengolahan ATC dengan menggunakan Response Surface Methodology (RSM). Penelitian ini diharapkan menjadi sumber informasi sebagai data dasar dalam proses peningkatan skala untuk pengolahan ATC.

\section{BAHAN DAN METODE}

\section{Bahan dan Alat}

Bahan utama yang digunakan adalah rumput laut kering jenis E.cottonii yang diperoleh dari Bali dengan jasa pengangkutan udara, sedangkan bahan kimia untuk alkalinisasi adalah kalium hidroksida $(\mathrm{KOH})$, serta bahan-bahan kimia pro analysis (p.a) untuk uji mutu diperoleh dari Toko Harum Kimia di Jakarta. Alat yang digunakan adalah waterbath, becker glass, timbangan, pengaduk, pH meter digital (Merk ATC tipe $\mathrm{pH} 108)$, hot plate, magnetic stirrer, TA.XT Plus Texture Analyser (Stable Micro Systems), oven pengering, mesin penepung, dan peralatan gelas untuk analisis mutu ATC.

\section{Metode}

Penelitian ini diawali dengan pengujian mutu bahan baku rumput laut kering yang meliputi kadar air dan Clean Anhydrous Weed (CAW). Tahap kedua 
penelitian ini adalah optimasi kondisi proses pengolahan ATC, yang tahapannya terdiri atas 4 tahap, yaitu 1) pembuatan rancangan formulasi dan respon, 2) formulasi, 3) analisis respon, 4) optimasi. Kemudian dilanjutkan ke tahap verifikasi, sebagai pembuktian terhadap prediksi dari nilai respon solusi formula optimum.

\section{Karakteristik Rumput Laut E. cottonii Kering}

Mutu rumput laut sebagai bahan baku dilakukan dengan uji kadar air (BSN, 2006) dan pengujian kadar Clean Anhydrous Weed (CAW) (Marine Colloids FMC Corp., 1977).

\section{Optimasi Kondisi Proses Pengolahan Alkali Treated Cottonii}

Ada empat tahap dalam mengaplikasikan RSM (Montgomery, 2001)

\section{Tahap pembuatan rancangan formulasi dan respon}

Pembuatan rancangan formulasi dan respon dilakukan dengan Program DX 7.0 ${ }^{\circledR}$ untuk menentukan variabel tetap dan variabel bebas. Variabel tetap adalah variabel yang nilainya dibuat sama dalam tiap perlakuan karena dianggap tidak mempengaruhi respon. Sedangkan variabel bebas adalah variabel yang akan mempengaruhi respon yang dihasilkan. Pada penelitian ini yang menjadi variabel tetap adalah jumlah rumput laut yang akan diolah dan variabel bebas adalah konsentrasi $\mathrm{KOH}$, suhu dan waktu pengolahan. Penentuan variabel bebas diperoleh berdasarkan kajian peneliti sebelumnya (Basmal et al., 2005; Mehta et al., 2008; Mustapha et al., 2011) dan dilakukan trial and error untuk menentukan batas minimum dan maksimum (Tabel 1).

Nilai batas minimum dan maksimum dimasukkan ke dalam program DX $7^{\circledR} R S M$ Box-Behnken Design untuk diacak. Setelah dilakukan pengacakan kombinasi, didapatkan 15 perlakuan yang akan dianalisis (Tabel 2) dan respon yang diukur dan dioptimasi adalah rendemen dan kekuatan gel.
Respon rendemen diukur menurut Neish (1989) dan respon kekuatan gel menurut Marine Colloids FMC Corp (1977).

\section{Penentuan rendemen (Neish, 1989)}

Rendemen dihitung sebagai persentase berat berdasarkan rasio berat antara berat ATC dengan berat rumput laut kering. Persentase rendemen dihitung dengan menggunakan rumus:

$$
\text { Rendemen (\%) }=\frac{\text { Berat ATC }}{\text { Berat rumput laut kering }} \times 100 \%
$$

\section{Penentuan kekuatan gel (Marine Colloids FMC Corp, 1977)}

Larutan karaginan dengan konsentrasi 1,5\% (b/b) dan $\mathrm{KCl}$ 0,6 g, dipanaskan di atas hot plate sambil diaduk secara teratur sampai suhu mencapai $80^{\circ} \mathrm{C}$ selama 15 menit. Larutan panas dimasukkan ke dalam cetakan berdiameter kira-kira $4 \mathrm{~cm}$ dan dibiarkan pada suhu $10^{\circ} \mathrm{C}$ selama $12-16$ jam. Plunger diaktifkan dan dilakukan pengamatan. Pengamatan dilakukan saat pegas membalik. Pembacaan gel dilakukan dengan alat Texture Analyzer.

\section{Tahap formulasi}

Tahap formulasi merupakan tahap pembuatan ATC sesuai dengan kondisi proses (formula) pada Tabel 2. Setiap formula akan dibuat ATC dari $200 \mathrm{~g}$ rumput laut. Proses pembuatannya dilakukan dengan proses seperti yang disajikan pada Gambar 1. Prosesnya diawali dengan persiapan bahan baku yang meliputi penimbangan rumput laut kering sebanyak $200 \mathrm{~g}$. Rumput laut yang telah ditimbang dicuci dengan air mengalir untuk menghilangkan benda asing termasuk pasir, karang, dan garam yang melekat pada rumput laut. Selanjutnya dilakukan proses pengolahan secara batch dengan perlakuan alkali $(\mathrm{KOH})$, sesuai dengan formula/kondisi proses yang dihasilkan oleh program. Konsentrasi $\mathrm{KOH}$, suhu dan waktu proses pengolahan akan menentukan kualitas ATC yang dihasilkan.

Tabel 1. Kisaran nilai variabel bebas

Table 1. The range of independent variable values

\begin{tabular}{clcc}
\hline $\begin{array}{c}\text { Komponen/ } \\
\text { Component }\end{array}$ & Variabel Independen/Independent Variable & $\begin{array}{c}\text { Minimuml } \\
\text { Minimum }\end{array}$ & $\begin{array}{c}\text { Maksimum/ } \\
\text { Maximum }\end{array}$ \\
\hline A & Konsentrasi KOH/KOH concentration (\%) & 6 & 8 \\
B & Suhu/Temperature $\left({ }^{\circ} \mathrm{C}\right)$ & 70 & 80 \\
$\mathrm{C}$ & Waktu/Time (Jam/hour) & 1 & 2 \\
\hline
\end{tabular}


Tabel 2. Rancangan percobaan pengolahan ATC Table 2. Experimental design of ATC processing

\begin{tabular}{cccc}
\hline \multirow{2}{*}{$\begin{array}{c}\text { Formula/ } \\
\text { Formula }\end{array}$} & Faktor 1/Factor 1 & Faktor 2/Factor 2 & Faktor 3/Factor 3 \\
\cline { 2 - 4 } & $\begin{array}{c}\text { A : Konsentrasi KOH/ } \\
\text { KOH concentration (\%) }\end{array}$ & $\begin{array}{c}\text { B : Suhu/Temperature } \\
\left({ }^{\circ} \text { C) }\right.\end{array}$ & $\begin{array}{c}\text { C : Waktu/Time } \\
\text { (Jam/Hour) }\end{array}$ \\
\hline 1 & 6 & 70 & 1.5 \\
2 & 8 & 70 & 1.5 \\
3 & 6 & 80 & 1.5 \\
4 & 8 & 80 & 1.5 \\
5 & 6 & 75 & 1.0 \\
6 & 8 & 75 & 1.0 \\
7 & 6 & 75 & 2.0 \\
8 & 8 & 75 & 2.0 \\
9 & 7 & 70 & 1.0 \\
10 & 7 & 80 & 1.0 \\
11 & 7 & 70 & 2.0 \\
12 & 7 & 80 & 2.0 \\
13 & 7 & 75 & 1.5 \\
14 & 7 & 75 & 1.5 \\
15 & 7 & 75 & 1.5 \\
\hline
\end{tabular}

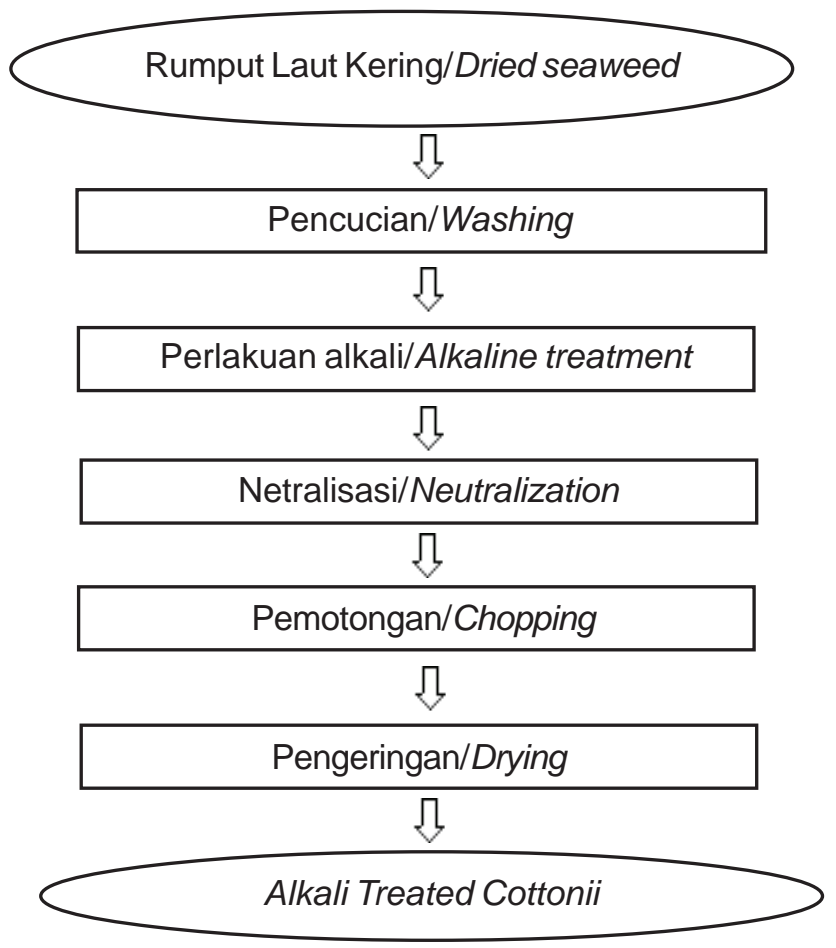

Gambar 1. Diagram alir pengolahan ATC.

Figure 1. Flow chart of ATC processing.

Kondisi proses alkalinisasi yang dilakukan pada tahap ini ditentukan berdasarkan pengujian trial and error yang merupakan sintesis hasil penelitian Basmal et al., 2005, Mehta et al., 2008, dan Mustapha et al., 2010). Setelah proses alkalinisasi selesai, dilanjutkan ke proses netralisasi dengan air sampai pH 8,5 (Bawa et al., 2007). Proses selanjutnya dilakukan pemotongan, yang kemudian dilanjutkan ke proses pengeringan menggunakan oven pada suhu $60^{\circ} \mathrm{C}$ selama 18 jam (Hoffmann et al., 1995). 


\section{Tahap analisis respon}

Setiap variabel respon kemudian dianalisa ANOVA satu persatu. Model ANOVA yang digunakan dapat dipilih sesuai yang disarankan oleh program yaitu model yang memiliki tingkat tertinggi dan menghasilkan nilai signifikan ANOVA. Model ANOVA yang terdapat pada design ini adalah Linear, Quadratic, Special Cubic, dan Cubic. Model yang memberikan signifikansi pada ANOVA dan non signifikansi pada lack of fit dipilih untuk menganalisis variabel. Selain itu, program DX $7.0^{\circledR}$ juga memberikan fasilitas plot kenormalan residual (normal plot of residual) yang mengindikasikan apakah residual (selisih antara respon aktual dengan nilai respon yang diprediksikan) mengikuti garis kenormalan (garis lurus). Titik-titik data yang semakin mendekati garis kenormalan menunjukkan data yang menyebar normal, yang berarti hasil aktual akan mendekati hasil yang diprediksikan oleh program DX $7.0^{\circledR}$ (Kumari et al., 2008).

\section{Tahap optimasi}

Pada tahap ini, masing-masing respon (rendemen dan kekuatan gel) ditentukan tujuan optimasinya dalam program $\mathrm{DX} 7.0^{\circledR}$. Program ini akan melakukan optimasi sesuai data variabel dan data pengukuran respon yang dimasukkan. Keluaran dari tahap optimasi adalah rekomendasi beberapa formula baru yang optimal menurut program. Formula paling optimal adalah formula dengan nilai desirability maksimum. Nilai desirability merupakan nilai fungsi tujuan optimasi yang menunjukkan kemampuan program untuk memenuhi keinginan berdasarkan kriteria yang ditetapkan pada produk akhir. Kisaran nilainya dari 0 sampai 1,0 . Nilai desirability yang semakin mendekati nilai 1,0 menunjukkan kemampuan program untuk menghasilkan produk yang dikehendaki semakin sempurna. Tujuan optimasi bukan untuk memperoleh nilai desirability 1,0, namun untuk mencari kondisi terbaik yang mempertemukan semua fungsi tujuan (Raissi \& Farzani, 2009).

Setelah diperoleh kondisi proses optimum, dilanjutkan ke tahapan verifikasi, yaitu dilakukan pengolahan dan analisis ATC sesuai dengan formulasi terbaik yang didapatkan dari hasil optimasi RSM. Verifikasi dilakukan dengan dua kali ulangan. Hasil yang diperoleh kemudian dibandingkan dengan nilai variabel respon yang diprediksi oleh RSM yang telah dilengkapi dengan prediksi nilai setiap respon sehingga dapat dilihat kesesuaiannya pada tahapan verifikasi (Anihouvi et al., 2011).

\section{HASIL DAN BAHASAN}

\section{Analisis Bahan Baku}

Hasil yang diperoleh dari uji mutu bahan baku dapat dilihat pada Tabel 3.

Berdasarkan Tabel 3, diketahui bahwa kadar air rumput laut kering yang dijadikan sampel uji pada penelitian ini adalah $36,47 \%$, nilainya sedikit lebih tinggi dari yang telah ditetapkan dalam SNI No.2690.1:2009, namun nilai tersebut masih memenuhi persyaratan permintaan industri-industri karaginan terhadap bahan baku rumput laut kering yang mensyaratkan kadar air maksimal 37\% (Anggadiredja, 2011). Sedangkan nilai CAW rumput laut masih berada dalam batas yang ditetapkan oleh SNI yang mensyaratkan CAW minimal 30\% (BSN, 2009).

\section{Optimasi Kondisi Proses Pengolahan dengan RSM}

Hasil pengukuran pengaruh kondisi proses pengolahan terhadap respon rendemen dan kekuatan gel dapat dilihat pada Tabel 4.

Berdasarkan Tabel 4 dapat dilihat bahwa kisaran nilai respon rendemen ATC adalah 33,05\% hingga $38,77 \%$, sedangkan nilai kekuatan gelnya berkisar antara $611,18 \mathrm{~g} / \mathrm{cm}^{2}$ sampai $1171,18 \mathrm{~g} / \mathrm{cm}^{2}$. Hasil analisis ragam (ANOVA) (Tabel 5), menunjukkan bahwa model yang terpilih untuk respon rendemen dan kekuatan gel adalah kuadratik (quadratic model), karena model ini yang memiliki $\mathrm{R}^{2}$ yang lebih besar dibandingkan dengan model yang lain yaitu 0,67 untuk rendemen dan 0,96 untuk kekuatan gel. Selain itu, model ini signifikan dengan nilai p lebih kecil dari 0,05 $(0,0037)$ untuk rendemen dan lebih kecil dari 0,05(< 0,0001 ) untuk kekuatan gel. Hasil ANOVA juga menunjukkan bahwa masing-masing komponen yaitu konsentrasi $\mathrm{KOH}$, suhu, waktu dan interaksi antar

Tabel 3. Hasil analisis dan syarat mutu rumput laut kering

Table 3. Results of analysis and quality requirements of dried seaweed

\begin{tabular}{lcc}
\hline \multicolumn{1}{c}{ ParameterlParameters } & $\begin{array}{c}\text { Rumput laut/ } \\
\text { Seaweed E. cottonii }\end{array}$ & SNI No.2690.1:2009 \\
\hline Kadar air/Moisture content (\%) & $36.47 \pm 0.08$ & Maks/Max 35 \\
Clean Anhydrous Weed $(\%)$ & $40.18 \pm 1.12$ & Min/Min 30 \\
\hline
\end{tabular}


Tabel 4. Rendemen dan kekuatan gel ATC berdasarkan kondisi pengolahan

Table 4. Yield and gel strength of ATC based on process conditions

\begin{tabular}{cccccr}
\hline $\begin{array}{c}\text { Formulal } \\
\text { Formula }\end{array}$ & KOH (\%) & $\begin{array}{c}\text { Suhul } \\
\text { Temperature }\left({ }^{\circ} \mathrm{C}\right)\end{array}$ & $\begin{array}{c}\text { Waktu/Time } \\
\text { (Jam/hours) }\end{array}$ & $\begin{array}{c}\text { Rendemen/ } \\
\text { Yield }(\%)\end{array}$ & $\begin{array}{c}\text { Kekuatan Gell } \\
\text { Gel Strength }\left(\mathbf{g} / \mathbf{c m}^{2} \text { ) }\right.\end{array}$ \\
\hline 1 & 6 & 70 & 1.5 & 38.77 & 611.18 \\
2 & 8 & 70 & 1.5 & 36.62 & 895.41 \\
3 & 6 & 80 & 1.5 & 35.39 & 1171.18 \\
4 & 8 & 80 & 1.5 & 33.05 & 1163.98 \\
5 & 6 & 75 & 1.0 & 38.68 & 935.82 \\
6 & 8 & 75 & 1.0 & 37.23 & 1076.21 \\
7 & 6 & 75 & 2.0 & 37.82 & 1076.2 \\
8 & 8 & 75 & 2.0 & 35.97 & 1087.6 \\
9 & 7 & 70 & 1.0 & 38.77 & 827.92 \\
10 & 7 & 80 & 1.0 & 37.63 & 988.31 \\
11 & 7 & 70 & 2.0 & 35.73 & 896.92 \\
12 & 7 & 80 & 2.0 & 35.64 & 1004.61 \\
13 & 7 & 75 & 1.5 & 37.80 & 867.95 \\
14 & 7 & 75 & 1.5 & 37.22 & 817.59 \\
15 & 7 & 75 & 1.5 & 38.36 & 835.76 \\
\hline
\end{tabular}

Tabel 5. Analisis model untuk respon rendemen dan kekuatan gel Table 5. Analysis model for yield response and gel strength

\begin{tabular}{|c|c|c|c|c|c|}
\hline $\begin{array}{l}\text { Respon/ } \\
\text { Response }\end{array}$ & Model & Matematika/Equation & $\begin{array}{c}\text { Signifikanl } \\
\text { Significant } \\
(p<0.05)\end{array}$ & $\begin{array}{c}\text { Lack of } \\
\quad \text { fit } \\
(p<0.05)\end{array}$ & $\mathrm{R}^{2}$ \\
\hline Rendemen/Yield & Kuadratik/Quadratic & $\begin{aligned} Y= & -0,97 A+6,59 B-1,79 C \\
& -0,045 B^{2}\end{aligned}$ & 0.0037 & 0.27 & 0.67 \\
\hline $\begin{array}{l}\text { Kekuatan gel/ } \\
\text { Gel strength }\end{array}$ & Kuadratik/Quadratic & $\begin{array}{l}Y=29030,24 A+1488,61 B \\
-521,90 C-406,91 A B- \\
64,50 A C-1984,79 A^{2} \\
+344,21 C^{2}+28,02 A^{2} B\end{array}$ & $<0.0001$ & 0.49 & 0.96 \\
\hline
\end{tabular}

suhu, berpengaruh nyata (signifikan) terhadap respon rendemen dan kekuatan gel. Lack of Fit F-Value respon rendemen dengan nilai $p$ lebih besar dari 0,05 $(0,27)$, dan $0,05(0,47)$ untuk kekuatan gel, menunjukkan Lack of Fit yang tidak signifikan. Nilai Lack of Fit yang tidak signifikan merupakan syarat untuk model yang baik karena menunjukkan adanya kesesuaian data respon rendemen dengan model (Keshani et al., 2010).

\section{Analisis Respon Rendemen}

Rendemen produk dari suatu pengolahan merupakan salah satu faktor yang memegang peranan penting dalam suatu proses industri dan pengembangan produk selanjutnya. Rendemen ATC merupakan indikator efisiensi dari proses pengolahan ATC.

Persamaan RSM untuk optimasi kondisi proses pengolahan ATC terhadap respon rendemen adalah sebagai berikut:

Rendemen $Y=-0,97 A+6,59 B-1,79 C-0,05 B^{2}$

Keterangan/Note:

A: Konsentrasi $\mathrm{KOH} / \mathrm{KOH}$ concentration;

B: Suhu/Temperature;

C: Waktu/Time. 
Persamaan tersebut menunjukkan bahwa respon rendemen akan meningkat berbanding lurus dengan peningkatan komponen suhu yang ditunjukkan dengan nilai konstanta yang positif. Hal ini disebabkan oleh suhu yang semakin tinggi akan memperlebar jarak antar molekul dalam suatu padatan, termasuk rumput laut (Foust, 1959). Renggangnya molekul dalam padatan rumput laut, menyebabkan alkali akan lebih mudah masuk sehingga karaginan yang terekstrak akan lebih banyak. Akan tetapi pada suhu $80^{\circ} \mathrm{C}$ rendemen karaginan menurun, karena terjadi degradasi yang semakin cepat yang pada akhirnya akan merusak material yang akan diproses dalam hal ini karaginan. Hal ini sejalan dengan pernyataan Stanley (1987) dan Neish (1989), bahwa pengolahan akan berlangsung cepat pada suhu yang tinggi, tetapi dapat mengakibatkan beberapa komponen dalam karaginan akan rusak.

Rendemen akan mengalami penurunan seiring dengan peningkatan waktu pengolahan, diikuti dengan peningkatan konsentrasi $\mathrm{KOH}$ dan interaksi antar suhu. Hal ini berkaitan dengan jaringan selulosa pada rumput laut yang menjadi lunak dengan konsentrasi $\mathrm{KOH}$ yang semakin tinggi, karena $\mathrm{KOH}$ selain sebagai agen demineralisasi, juga berfungsi sebagai agen hidrolisis (Griffin, 1970).

Grafik normal plot of residual yang mengindikasikan hubungan antara nilai aktual dan nilai yang diprediksikan pada Gambar 2, mendekati garis kenormalan yang menunjukkan data untuk respon rendemen menyebar normal. Hal ini berarti bahwa hasil aktual akan mendekati hasil yang diprediksikan oleh Program DX 7.0 ${ }^{\circledR}$ (Kumari et al., 2008).

Grafik contour plot pada Gambar 3, menunjukkan bagaimana kombinasi antar komponen saling mempengaruhi nilai respon rendemen. Warna-warna yang berbeda pada grafik contour plot menunjukkan nilai rendemen. Warna biru menunjukkan nilai respon rendemen terendah, yaitu 35,18\%. Warna merah menunjukkan respon rendemen tertinggi, yaitu $38,07 \%$. Garis-garis yang terdiri atas titik-titik pada grafik contour plot menunjukkan kombinasi dari ketiga komponen dengan jumlah berbeda yang menghasilkan respon rendemen yang sama. Bentuk permukaan dari hubungan interaksi antar komponen ini dapat dilihat lebih jelas pada grafik tiga dimensi yang ditunjukkan pada Gambar 4.

Secara keseluruhan kisaran nilai rendemen ATC yang dihasilkan dalam penelitian ini sudah memenuhi standar minimum karaginan yang dipersyaratkan oleh Departemen Perdagangan 1989, yaitu sebesar 25\%.

\section{Analisis Respon Kekuatan Gel}

Kekuatan gel dinyatakan sebagai breaking force yang didefinisikan sebagai beban maksimum yang dibutuhkan untuk memecahkan matrik polimer pada daerah yang dibebani (Whyte \& Englar, 1980). Semakin berat beban yang diperlukan maka kekuatan gel yang dihasilkan akan semakin tinggi. Kekuatan gel sangat penting untuk menentukan perlakuan yang terbaik dalam proses pengolahan karaginan.
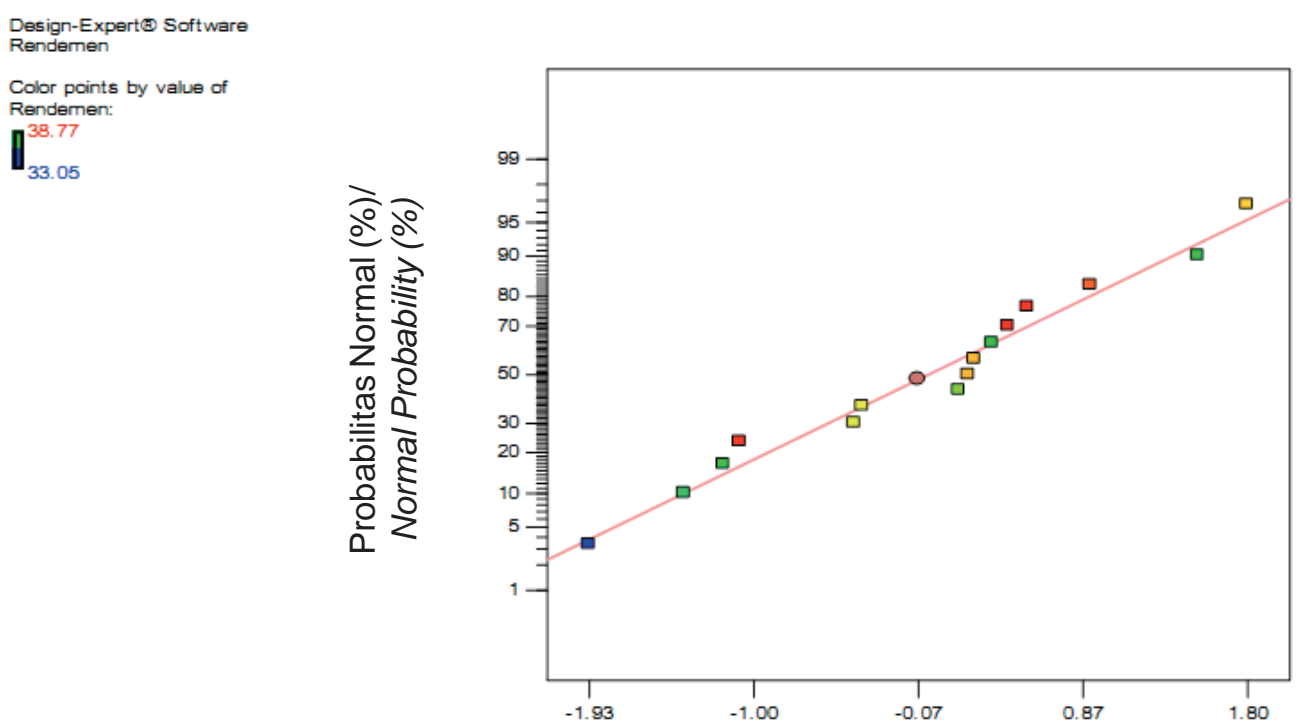

Residual internal studentize/ Internally studentized residuals

Gambar 2. Plot kenormalan residual respon rendemen.

Figure 2. Normal plot of residuals of yield response. 

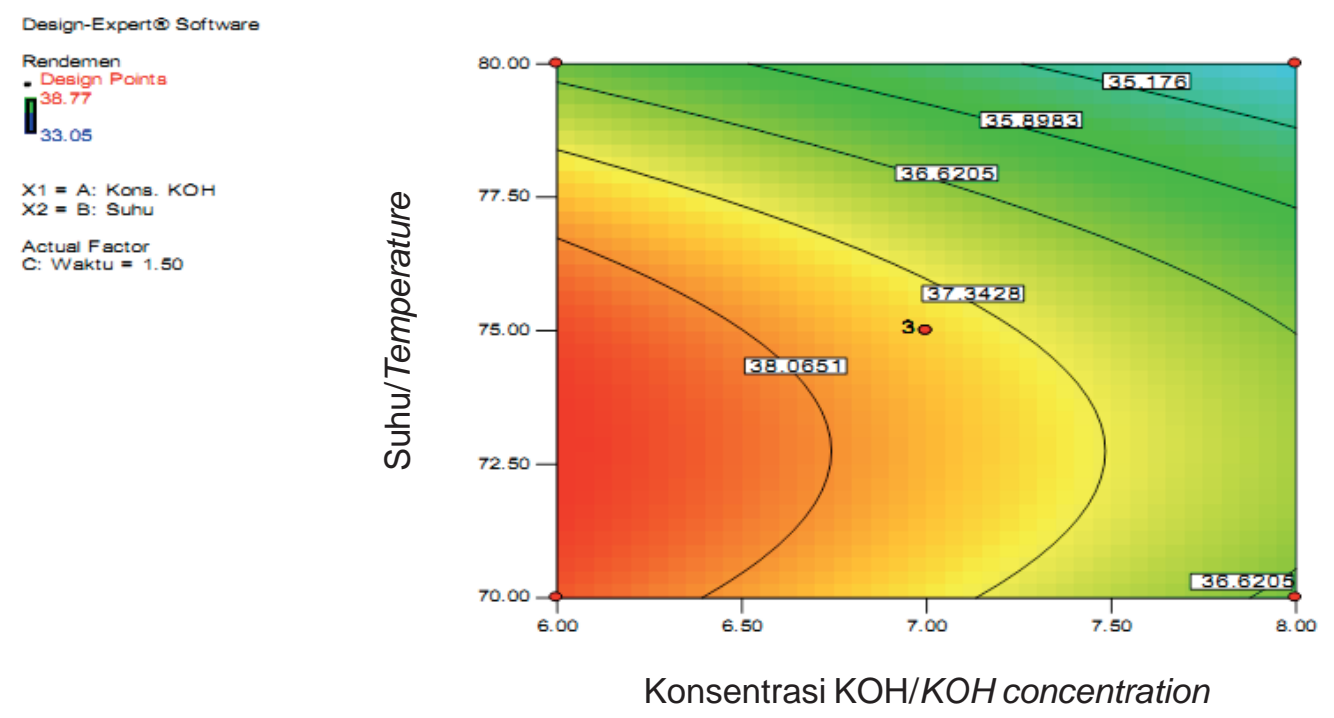

Gambar 3. Grafik contour plot hasil uji respon rendemen.

Figure 3. Contour plot graph of yield response test.
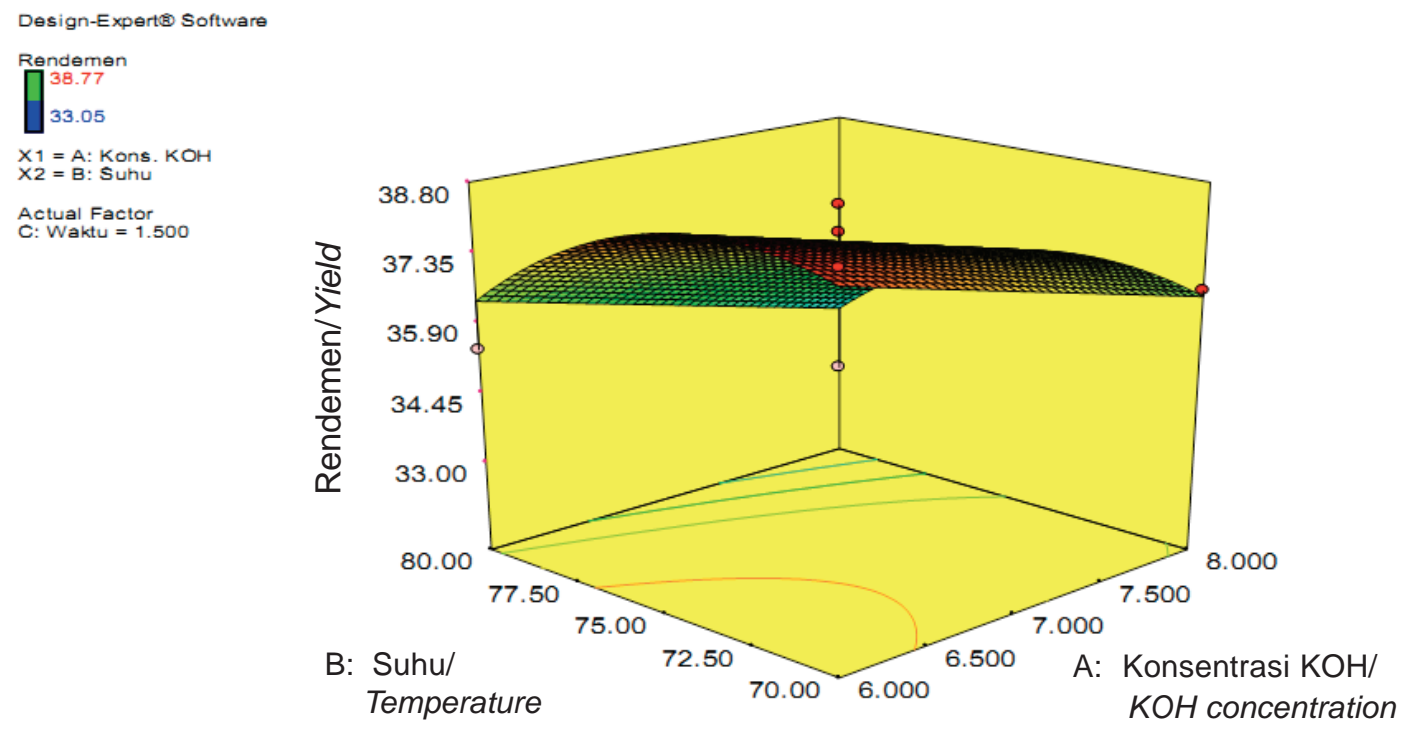

Gambar 4. Grafik tiga dimensi hasil uji respon rendemen.

Figure 4. Three-dimensional graph of yield response test.

Kemampuan membentuk gel merupakan salah satu sifat karaginan yang menjadi dasar penggunaannya pada berbagai industri.

Persamaan RSM untuk optimasi kondisi proses pengolahan rumput laut untuk memperoleh ATC dengan kekuatan gel yang maksimum adalah sebagai berikut:

Kekuatan gel $=29030,24 \mathrm{~A}+1488,61 \mathrm{~B}-521,90 \mathrm{C}-$ $406,91 A B-64,50 A C-1984,79 A^{2}+$ $344,21 C^{2}+28,02 A^{2} B$
Keterangan/Note:

A: Konsentrasi $\mathrm{KOH} / \mathrm{KOH}$ concentration;

B: Suhu/Temperature;

C: Waktu/Time.

Persamaan tersebut menunjukkan bahwa respon kekuatan gel akan meningkat berbanding lurus dengan konsentrasi $\mathrm{KOH}$, suhu, interaksi antar waktu dan interaksi antar konsentrasi $\mathrm{KOH}$ dan suhu. Hal ini ditunjukkan dengan nilai konstanta yang positif. Respon kekuatan gel akan mengalami penurunan 
seiring dengan peningkatan waktu, interaksi antara konsentrasi $\mathrm{KOH}$ dan suhu, interaksi antara konsentrasi $\mathrm{KOH}$ dengan waktu dan interaksi antar konsentrasi $\mathrm{KOH}$. Hal ini ditunjukkan dengan nilai konstanta yang negatif. Namun pada Gambar 7, diperlihatkan bahwa kenaikan dan penurunan suhu secara nyata hanya dipengaruhi oleh komponen suhu dan konsentrasi $\mathrm{KOH}$. Hal ini disebabkan karena peningkatan temperatur mempercepat proses transformasi gugus sulfat oleh ion $\mathrm{K}^{+}$dari larutan $\mathrm{KOH}$ dan membentuk kalium sulfat di larutan. Sifat sulfat yang mengikat molekul air mudah menguap, sehingga ikut teruapkan dengan adanya panas (eliminasi sulfat). Eliminasi sulfat menyebabkan kekuatan gel meningkat karena pembentukan 3,6 anhidrogalaktosa menjadi sempurna, hasil akhir dari reaksi tersebut, terjadi pembentukan kappa karaginan dan air (Towle, 1973; Hayashi et al., 2007; Mustapha et al., 2011). Meskipun demikian, peningkatan variasi suhu dan konsentrasi $\mathrm{KOH}$ yang terus menerus cenderung menyebabkan turunnya kekuatan gel. Hal ini disebabkan oleh terjadinya degradasi dan hidrolisis karaginan (Grifftin, 1970; Guiseley et al., 1980).

Grafik kenormalan internally stundentized residual pada Gambar 5 menunjukkan data untuk respon kekuatan gel yang menyebar normal. Grafik contour plot pada Gambar 6 menunjukkan kombinasi antara
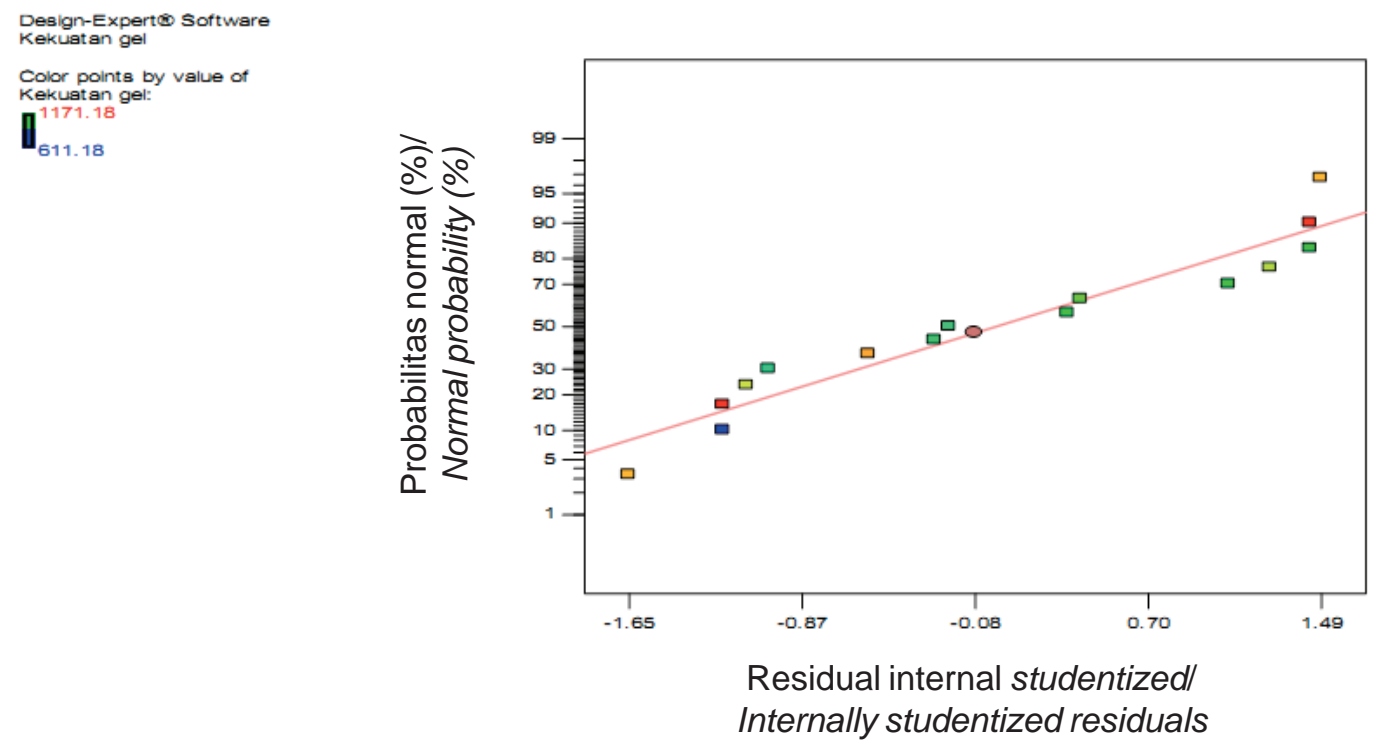

Gambar 5. Plot kenormalan residual respon kekuatan gel. Figure 5. Normal plot of residuals of gel strength response.
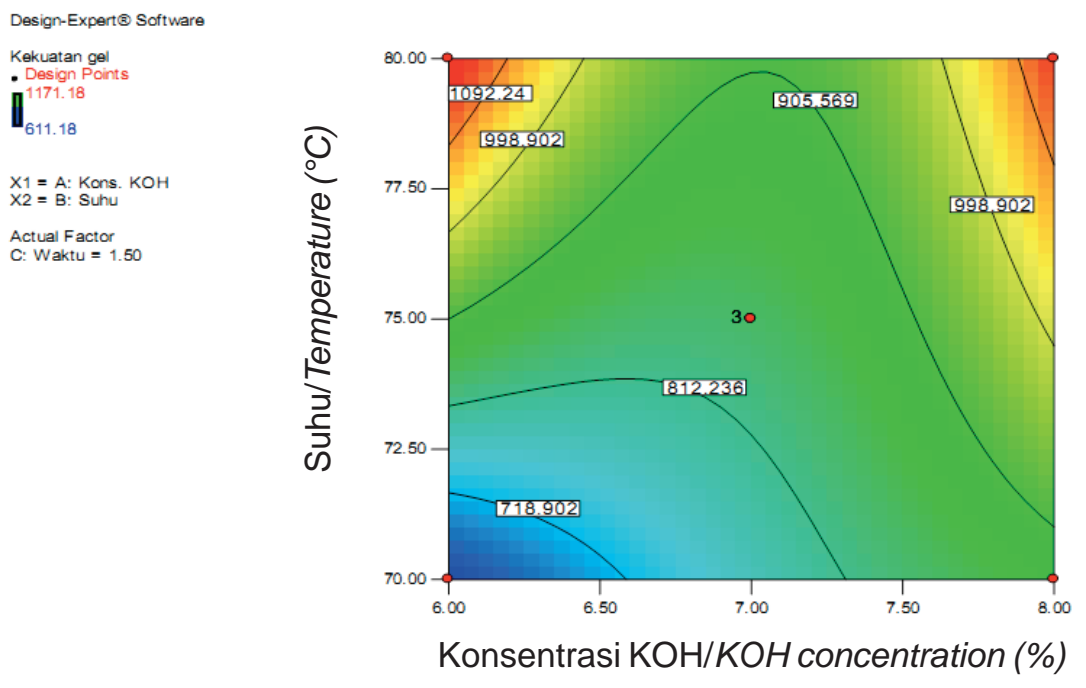

Gambar 6. Grafik contour plot hasil kekuatan gel.

Figure 6. Contour plot of gel strength response. 

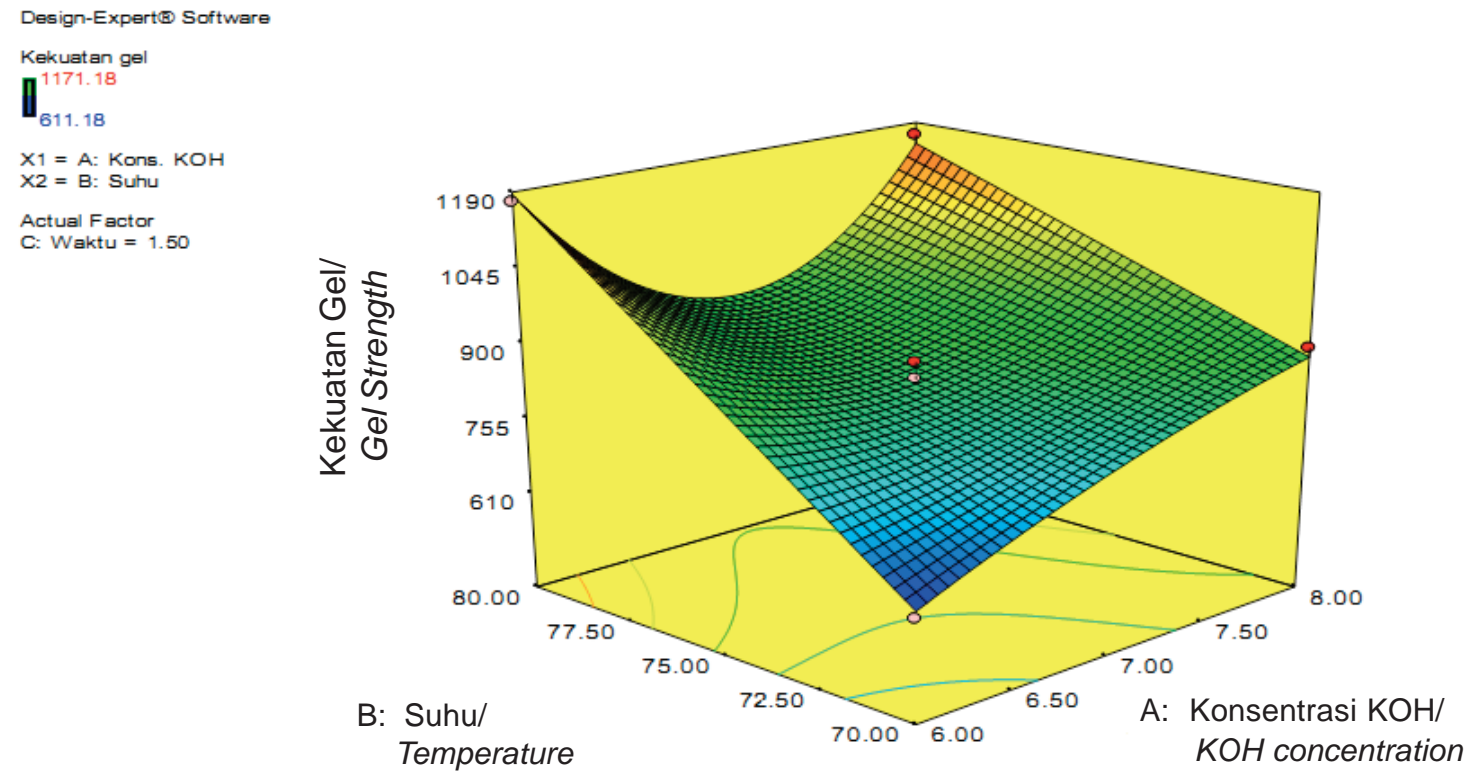

Gambar 7. Grafik tiga dimensi respon kekuatan gel.

Figure 7. Three-dimensional graph of gel strength response.

komponen yang saling mempengaruhi terhadap nilai respon kekuatan gel, melalui warna-warna yang berbeda. Garis-garis yang terdiri atas titik-titik pada grafik contour plot merupakan kombinasi antara tiga komponen formula kondisi proses pengolahan dengan proporsi berbeda yang menghasilkan nilai respon kekuatan gel yang sama. Grafik tiga dimensi (3-D) pada Gambar 7 merupakan bentuk permukaan dari interaksi antar komponen formula kondisi proses pengolahan.

\section{Optimasi Kondisi Proses Pengolahan ATC}

Optimasi dilakukan setelah didapat model matematika untuk masing-masing respon. Optimasi dilakukan untuk mendapatkan respon yang sesuai dengan yang diinginkan (desirability). Tujuan dari optimasi untuk meminimumkan usaha yang diperlukan atau biaya operasional dan memaksimumkan yang diinginkan. Tabel 5, menunjukkan komponenkomponen yang dioptimasi, targetnya, batas minimum dan maksimumnya, serta tingkat kepentingan pada tahap optimasi formula.

Konsentrasi $\mathrm{KOH}$ dengan kisaran 6-8\% merupakan komponen yang dioptimalkan dengan target minimal (6\%) dengan tingkat kepentingan $3(+++)$. Hal ini berhubungan dengan penerapannya di lapangan yaitu sebaiknya penggunaan $\mathrm{KOH}$ diminimalisasi, tanpa mengurangi fungsinya terhadap mutu ATC yang dihasilkan. Di samping dari segi efisiensi juga akan berdampak pada lingkungan.

Tabel 5. Komponen respon yang dioptimasi, target, batas, dan kepentingan pada tahapan optimasi formula. Table 5. Components and optimized response, goal, limits, and importance in the optimization stages of the formula

\section{Komponen Respon/ Response Component}

\begin{tabular}{lcrrc}
\hline Kons. $\mathrm{KOH} / \mathrm{KOH}$ concentration (\%) & Minimal/Minimum & 6.00 & 8.00 & $3(+++)$ \\
Suhu/Temperature $\left({ }^{\circ} \mathrm{C}\right)$ & Kisaran/range & 70.00 & 80.00 & $3(+++)$ \\
Waktu/Time $(\mathrm{Jam} / \mathrm{h})$ & Kisaran/range & 1.00 & 2.00 & $3(+++)$ \\
Rendemen/Yield $(\%)$ & Maksimal/Maximum & 33.05 & 38.77 & $5(+++++)$ \\
Kekuatan gel/Gel strength $\left(\mathrm{g} / \mathrm{cm}^{2}\right)$ & Maksimal/Maximum & 611.12 & 1171.18 & $5(+++++)$ \\
\hline
\end{tabular}
Batas Bawahl Batas Atasl Kepentingan/
Lower Limit

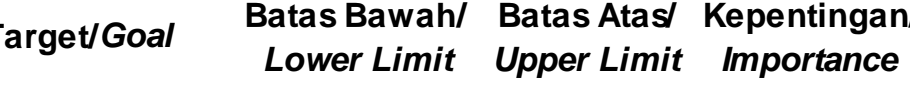


Sedangkan suhu dan waktu pengolahan dioptimalkan dengan kisaran 70 sampai $80^{\circ} \mathrm{C}$ dengan tingkat kepentingan $3(+++)$. Suhu dan lamannya waktu pengolahan akan mempengaruhi kualitas karaginan yang dihasilkan.

Respon rendemen dan kekuatan gel merupakan respon yang dioptimalkan dengan target maksimal dengan tingkat kepentingan 5(+++++). Rendemen merupakan respon yang sangat menentukan efisiensi proses suatu usaha, hubungannya dengan nilai ekonomi yang akan memberikan keuntungan, demikian pula kekuatan gel, erat kaitannya dengan sifat fungsionalnya yang dibutuhkan oleh berbagai industri.

Berdasarkan proses optimasi, program DX $7.0^{\circledR}$ memberikan 19 solusi formula optimum yang dapat dilihat pada Tabel 6 . Kondisi proses dengan konsentrasi $\mathrm{KOH} 6 \%$, suhu $78,67^{\circ} \mathrm{C}$, dengan waktu 1 jam direkomendasikan sebagai solusi formula yang optimal, karena kondisi proses ini memiliki nilai desirability yang tinggi yaitu 0,928 . Montgomery (2001), menyatakan bahwa nilai desirability tersebut adalah untuk menentukan derajat ketepatan hasil solusi optimal. Nilai desirability yang mendekati satu maka semakin tinggi nilai ketepatan optimasi, sehingga bisa disimpulkan bahwa kondisi proses dengan konsentrasi $\mathrm{KOH} 6 \%$, suhu $78,67^{\circ} \mathrm{C}$, dengan waktu 1 jam akan menghasilkan produk ATC yang memiliki karakteristik yang sesuai dengan target optimasi sebesar 92,8\%, dan diprediksi menghasilkan produk ATC dengan rendemen $38,09 \%$ dan kekuatan gel $1135,5 \mathrm{~g} / \mathrm{cm}^{2}$.

Gambar 8 dan 9, menjelaskan hasil optimasi dalam bentuk contour (2D) dan tiga dimensi (3D). Contour plot merupakan gambaran dua dimensi dari respon yang disajikan dengan menggunakan model prediksi untuk nilai respon rendemen dan kekuatan gel. Garisgaris yang terdiri atas titik-titik pada grafik contour plot menunjukkan kombinasi dari ketiga komponen dengan jumlah berbeda yang menghasilkan nilai desirability tertentu yang sama. Titik prediksi pada gambar tersebut menunjukkan kombinasi antara konsentrasi $\mathrm{KOH} 6 \%$, suhu $78,67^{\circ} \mathrm{C}$ dan waktu 1 jam yang menghasilkan nilai desirability sebesar 0,928. Grafik tiga dimensi (3-D) menunjukkan proyeksi dari

Tabel 6. Formula yang dihasilkan dalam tahapan optimasi

Table 6. Formula resulted from optimization phase

\begin{tabular}{ccccccc}
\hline No & $\begin{array}{c}\text { KOH } \\
(\%)\end{array}$ & $\begin{array}{c}\text { Suhul } \\
\text { Temperature } \\
\left({ }^{\circ} \mathbf{C}\right)\end{array}$ & $\begin{array}{c}\text { Waktul } \\
\text { Time } \\
\text { (jam/h) }\end{array}$ & $\begin{array}{c}\text { Rendemen/ } \\
\text { Yield } \mathbf{( \% )}\end{array}$ & $\begin{array}{c}\text { Kekuatan Gell } \\
\text { Gel Strength } \\
\left(\mathbf{g}_{\mathbf{c m}} \mathbf{)}\right)\end{array}$ & $\begin{array}{c}\text { Keinginan/ } \\
\text { Desirability }\end{array}$ \\
\hline $1^{*}$ & 6.00 & 78.67 & 1.00 & 38.09 & 1135.50 & 0.928 \\
2 & 6.00 & 78.58 & 1.00 & 38.14 & 1130.00 & 0.928 \\
3 & 6.00 & 78.76 & 1.00 & 38.04 & 1139.50 & 0.928 \\
4 & 6.00 & 79.08 & 1.00 & 37.86 & 1158.10 & 0.927 \\
5 & 6.00 & 79.30 & 1.00 & 37.73 & 1170.72 & 0.926 \\
6 & 6.00 & 77.82 & 1.00 & 38.51 & 1087.75 & 0.923 \\
7 & 6.01 & 78.70 & 1.00 & 38.06 & 1131.90 & 0.923 \\
8 & 6.03 & 78.50 & 1.00 & 38.15 & 1114.34 & 0.915 \\
9 & 6.00 & 78.35 & 1.05 & 38.17 & 1107.33 & 0.915 \\
10 & 6.00 & 77.10 & 2.00 & 37.03 & 1171.14 & 0.870 \\
11 & 6.00 & 77.02 & 2.00 & 37.06 & 1166.45 & 0.870 \\
12 & 6.00 & 76.79 & 2.00 & 37.15 & 1153.49 & 0.869 \\
13 & 6.00 & 76.65 & 2.00 & 37.20 & 1145.75 & 0.868 \\
14 & 6.01 & 76.95 & 2.00 & 37.09 & 1160.53 & 0.867 \\
15 & 6.00 & 77.43 & 1.96 & 36.97 & 1171.18 & 0.865 \\
16 & 6.04 & 77.43 & 2.00 & 36.86 & 1174.27 & 0.851 \\
17 & 6.00 & 78.64 & 1.45 & 37.30 & 1104.04 & 0.849 \\
18 & 6.00 & 77.95 & 1.66 & 37.27 & 1099.50 & 0.844 \\
19 & 6.00 & 78.12 & 1.61 & 37.28 & 1097.67 & 0.844 \\
\hline
\end{tabular}

Keterangan/Note: *: Terpilih/Selected 

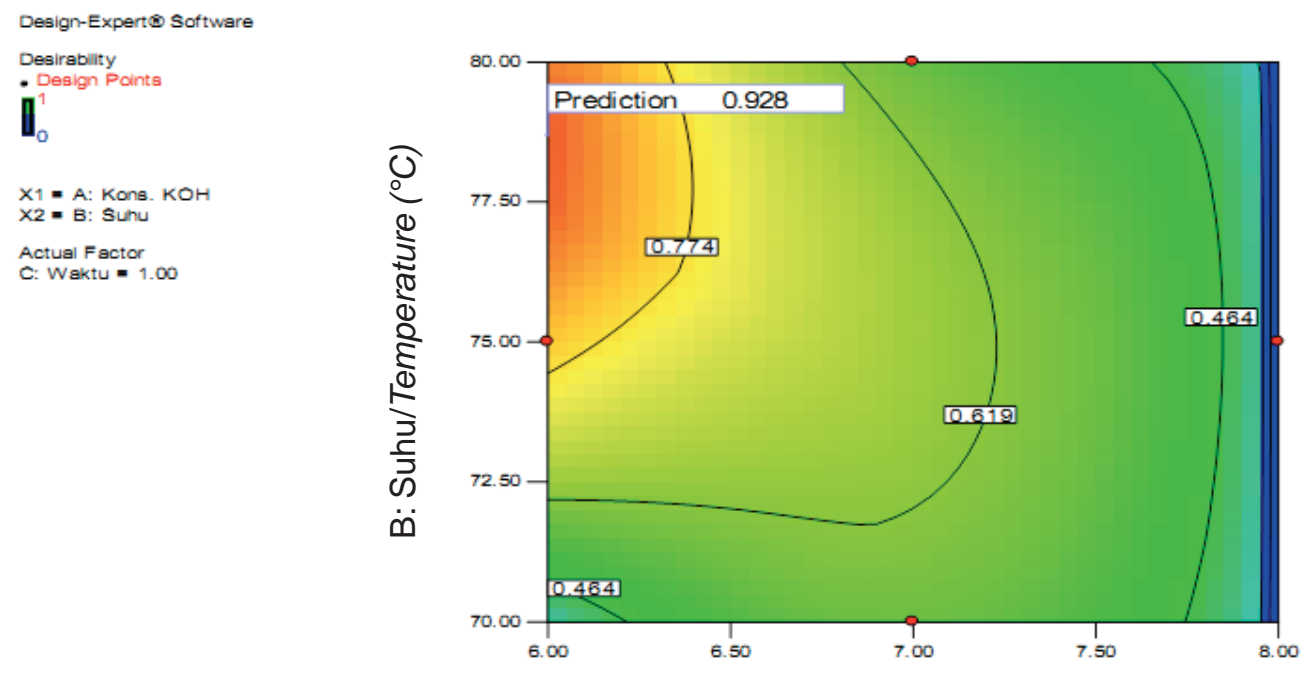

A: Konsentrasi $\mathrm{KOH} / \mathrm{KOH}$ concentration (\%)

Gambar 8. Grafik contour plot nilai desirability formula optimum.

Figure 8. Contour plot graph of desirability value of optimum formula.

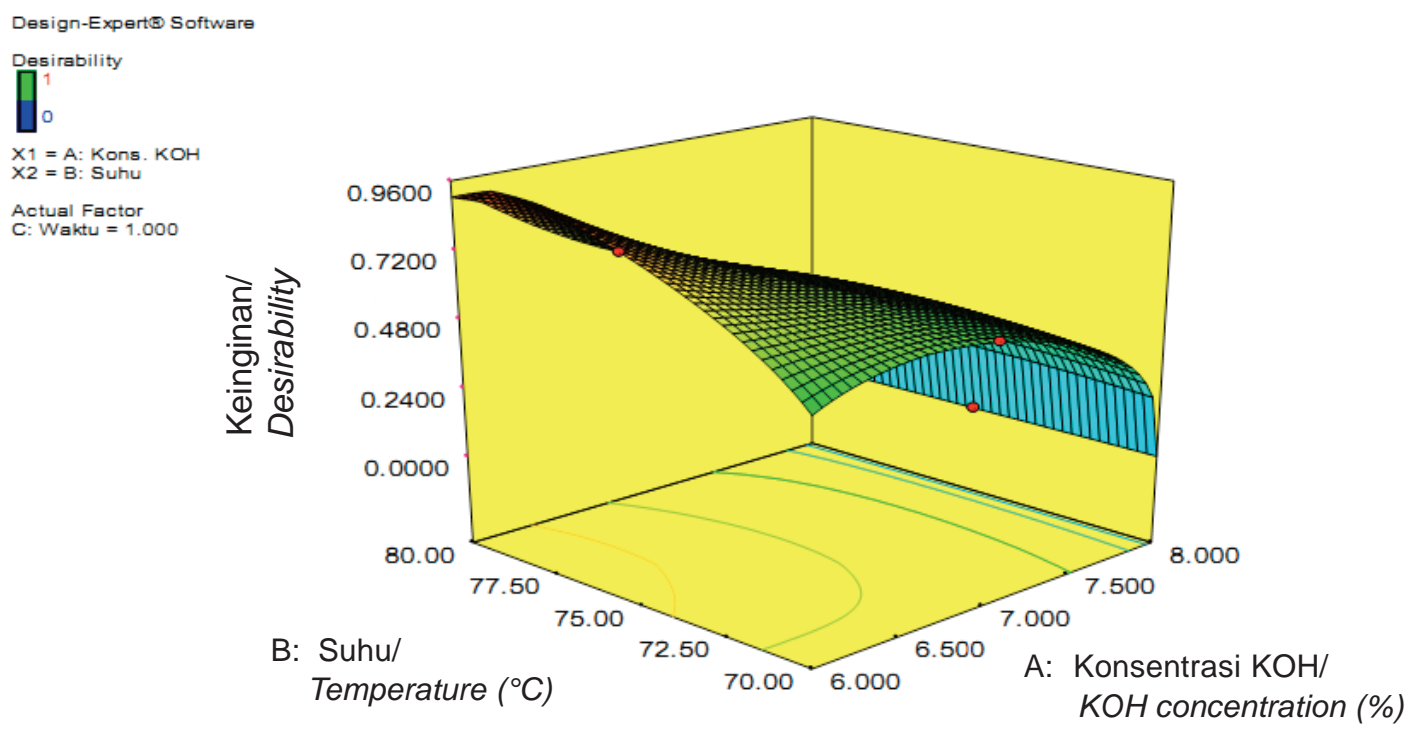

Gambar 9. Grafik tiga dimensi nilai desirability formula optimum.

Figure 9. Three-dimensional graph of desirability value of optimum formula.

grafik contour plot. Area yang rendah pada grafik tiga dimensi menunjukkan nilai desirability yang rendah, sedangkan area yang tinggi menunjukkan nilai desirability yang tinggi.

\section{Verifikasi Solusi Formula Optimum}

Pada hasil verifikasi kondisi optimum yang direkomendasikan program $\mathrm{DX} 7.0^{\circledR}$ dengan $R S M$-BoxBehnken, diperoleh ATC dengan rendemen 38,72\%, dan kekuatan gel $1105,31 \mathrm{~g} / \mathrm{cm}^{2}$. Jika dibandingkan dengan nilai yang diprediksikan (Tabel 7), maka nilai hasil verifikasi berada di kisaran 95\% PI low dan 95\% $P I$ high. Hal ini berarti kondisi proses pengolahan untuk memperoleh ATC dengan rendemen dan kekuatan gel yang maksimum, cukup konsisten (Noordin et al., 2004).

\section{KESIMPULAN}

Terjadi interaksi komponen-komponen proses pengolahan antara konsentrasi $\mathrm{KOH}$, suhu dan waktu 
Tabel 7. Prediksi dan hasil verifikasi nilai respon solusi formula optimum hasil optimasi dengan program Design Expert 7.0 ${ }^{\circledR}$.

Table 7. Predicted and verified response value of optimum formula from optimization using Design Expert 7.0 $0^{\circledR}$ program.

\begin{tabular}{lcccccc}
\hline \multirow{2}{*}{ Respon/Response } & \multicolumn{5}{c}{ Formula/Formula } \\
\cline { 2 - 7 } & $\begin{array}{c}\text { Prediksil } \\
\text { Prediction }\end{array}$ & $\begin{array}{c}\text { Verifikasil } \\
\text { Verification }\end{array}$ & $\begin{array}{c}\text { 95\% Cl } \\
\text { Rendah/Low }\end{array}$ & $\begin{array}{c}\text { 95\% Cl } \\
\text { Tinggi/High }\end{array}$ & $\begin{array}{c}\text { 95\% Pendah/Low } \\
\text { Ringgi/High }\end{array}$ \\
\hline Rendemen/Yield (\%) & 38.09 & 38.72 & 36.82 & 39.36 & 35.67 & 40.5 \\
$\begin{array}{l}\text { Kekuatan gel/ } \\
\text { Gel strength }\left(\mathrm{g} / \mathrm{cm}^{2}\right)\end{array}$ & 1135.5 & 1105.31 & 1069.5 & 1201.5 & 1041.3 & 1229.75 \\
\hline
\end{tabular}

pengolahan terhadap rendemen dan kekuatan gel ATC. Perbedaan kondisi proses pengolahan berpengaruh terhadap rendemen dan kekuatan gel dari ATC yang dihasilkan.

Optimasi menggunakan Program DX $7.0^{\circledR}$ dengan RSM-Box-Behnken menghasilkan formula pengolahan yang optimal dengan konsentrasi $\mathrm{KOH} 6 \%$, suhu $78,67^{\circ} \mathrm{C}$ selama 1 jam. Pada kondisi ini dihasilkan ATC dengan rendemen sebesar $38,72 \%$ dan kekuatan gel $1105,31 \mathrm{~g} / \mathrm{cm}^{2}$.

\section{UCAPAN TERIMA KASIH}

Ucapan terima kasih disampaikan kepada Kepala Balai Besar Penelitian dan Pengembangan Pengolahan Produk dan Bioteknologi Kelautan dan Perikanan, beserta jajarannya yang telah membantu terselesainya penelitian ini.

\section{DAFTAR PUSTAKA}

Anggadiredja, J.T. 2011. Kajian Strategi Pengembangan Industri Rumput Laut dan Pemanfaatannya secara Berkelanjutan. BPPT-PRESS, Jakarta.

Anihouvi, V.B., Saalia, F., Dawson, S.E., Ayernor, G.S., and Hounhouigan, J.D. 2011. Response surface methodology for optimizing the fermentation conditions during the processing of cassava fish (Pseudotolithus sp) into Lanhouin. International Journal of Engineering Science and Technology 3(9): 7085-7095.

Bas, D. and Boyaci, I.H. 2007. Modelling and optimization I: usability of response surface methodology. J. Food Eng. 78: 836-845.

Basmal, J., Suryaningrum, T.D., dan Yeni, Y. 2005. Pengaruh konsentrasi larutan potasium hidroksida terhadap karaginan kertas. Jurnal Penelitian Perikanan Indonesia. 11(8): 1-9.

Badan Standardisasi Nasional (BSN). 2006. Cara Uji Kimia-Bagian 2: Penentuan Kadar Air pada Produk Perikanan. SNI 01-2354.2-2006. Jakarta.
Badan Standardisasi Nasional (BSN). 2009. Standar Nasional Indonesia Rumput Laut Kering. SNI No.2690.1: 2009. BSN, Jakarta.

Bawa, A., Putra, B., dan Laila, I.R. 2007. Penentuan pH optimum isolasi karaginan dari rumput laut jenis Eucheuma cottonii. Jurnal Kimia. 1(1): 15-20.

Departemen Perdagangan. 1989. Ekspor Rumput Laut Indonesia. Departemen Perdagangan, Jakarta. 57 p.

Foust, A.S. 1959. Principles of Unit Operations. McGrawHill Book Company, Singapore.

Griffin, R.W. 1970. Modern Organic Chemistry. International Student Edition. McGraw-Hill International Book Company, London Tokyo Singapure.

Guiseley, K.B., Stanley, N.F, and Whitehouse, P.A. 1980. Carrageenan. In. Whistler, R.L. (ed.). Handbook of Water Soluble Gums and Resins. McGrow Hill Book Co., New York. pp.1-29

Hayashi, L., Oliveira, E.C., Lhonneur, G.B., Boulenguer, P., Pereira, R.T.L., Seckendorff, R.V., Shimoda, V.T., Leflamand, A., Vallée, P., and Critchley, A.T. 2007. The effects of selected cultivation conditions on the carrageenan characteristics of Kappaphycus alvarezii (Rhodophyta, Solieriaceae) in Ubatuba Bay, São Paulo, Brazil. J. Appl Phycol. 19: 505-511.

Hoffmann, R., Gi, M., Cooke, D., and Frith, W. 1995. Effect of isolation procedures on the molecular composition and physical properties of Eucheuma cottonii carrageenan. Food Hydrocolloids. 9: 281-289.

Iriawan, N., dan Astuti, S.P. 2006. Mengolah Data Statistik dengan Mudah Menggunakan Minitab 14. Yogyakarta. Penerbit ANDI.

Kementerian Kelautan dan Perikanan (KKP). 2012. Statistik Perikanan Indonesia. Kementerian Kelautan dan Perikanan, Jakarta.

Keshani, S., Chuah, A.L., Nourouzi, M.M., Russly, A.R., and Jamilah, B. 2010. Optimization of concentration process on pomelo fruit juice using response surface methodology (RSM). International Food Research Journal 17: 733-742.

Kumari, K.S., Babu, I.S., and Rao, G.H. 2008. Process optimization for citric acid production from raw glycerol 
using response surface methodology. Indian Journal of Biotechnology pp. 496-501.

Marine Colloids FMC Corp. 1977. Carrageenan. Marine colloids monograph number one. Marine colloid Division FMC Coorporation. Springfield, New Jersey, USA.

Mc Hugh, D.J. 2003. A Guide to The Seaweed Industry. FAO Fisheries Technical Paper. FAO, Rome.

Mehta, A.S., Mody, K.H., Iyer, A., and Ghosh, P.K. 2008. Preparation of semi-refined k-carrageenan: Recycling of alkali solution and recovery of alkali from spent liquor. Indian Journal of Chemical Technology. 15: 45-52.

Montgomery, D.C. 2001. Design and Analysis of Experimental. John Wiley \& Sons Inc, New York.

Mustapha, S., Chandar, H., Abidin, Z.Z., Saghravani, R., and Harun, M.Y. 2011. Production of semi-refined carrageenan from Eucheuma cottonii. Journal of Scientific Industrial Research. 70: 865-870.

Neish, I.C. 1989. Alkali Treatment of Carrageenan bearing Seaweeds Past, Present and Future. FMC Corporation, Marine Colloid Div. $11 \mathrm{p}$.

Noordin, M.Y., Venkatesh, V.C., Sharif, S., Elting, S., and Abdullah, A. 2004. Application of response surface methodology in describing the performance of coated carbide tools when turning AISI 1045 steel. J. Materials Processing Technology. 145:46-58.

Raissi, S., and Farzani, R.E. 2009. Statistical process optimization through multi-response surface methodology. World Academy of Science, Engineering and Technology. pp. 267-271.

Radojkovic, M., Zekovic, Z., Jokic, S., and Vidovic, S. 2012. Determination of optimal extraction parameters of mulberry leaves using Response Surface Methodology (RSM). Romanian Biotechnological Letters. 17(3): 7295-7308.

Stanley, N. 1987. Production, properties and uses of carrageenan. In Mc Hugh, D.J. (ed). Production and Utilization of Products from Commercial Seaweeds. FAO Fish Tech Paper. 288: 116-146.

Towle, G.A. 1973. Carrageenan. In Whistler, R.L. (ed.). Industrial Gums. Academic Press, New York.

Tuvikene, R., Truus, Vaher, M., Kailas, T., Martin, G., and Kersen. 2006. Extraction and quantification of hybrid carrageenans from the biomass of the red algae Furcellaria lumbricalis and Coccotylus truncatus. Proc. Estonian Acad. Sci. Chem. 55(1): 40-53.

Whyte, A. and Englar, T. 1992. Carrageenan. In Imeson A. (ed.). Thickening and Gelling Agents for Food. Blackie Academic and Professional, London. 